\title{
Efektivitas Formula Krim Tabir Surya Berbahan Aktif Ekstrak Etanol Biji Wali (Brucea javanica L. Merr)
}

\section{Effectivity of Sunscreen Cream Formulation Containing Ethanolic Extract of Wali (Brucea javanica L. Merr) Seed}

\author{
Almira Amini", Candra Dwipayana Hamdin, Windah Anugrah Subaidah, Handa Muliasari \\ Program Studi Farmasi, Fakultas Kedokteran, Universitas Mataram, Mataram, Indonesia \\ *Email: Almira.amini@ymail.com
}

Diterima: 2 Agustus 2019

Direvisi: 13 Oktober 2019

Disetujui: 16 Oktober 2019

\begin{abstract}
Abstrak
Intensitas sinar ultraviolet (UV) yang tinggi dapat menimbulkan efek negatif seperti eritema, sunburn, pigmentasi, penuaan dini pada kulit, dan kanker kulit. Efek tersebut dapat dicegah dengan penggunaan tabir surya. Wali (Brucea javanica L. Merr) merupakan salah satu tanaman dimana hampir seluruh bagiannya mengandung senyawa fenolik seperti fenol dan flavonoid. Senyawa tersebut terbukti memiliki efek sebagai tabir surya. Penelitian ini bertujuan untuk memformulasi dan menguji efektivitas krim tabir surya tipe minyak dalam air (M/A) dari biji buah Wali dengan konsentrasi $1 \%$. Pembuatan krim dilakukan dengan metode peleburan dan uji efektivitas krim dilakukan secara in vivo pada kulit mencit (Mus musculus). Krim tabir surya yang dibuat diuji sifat fisik dan efektivitas krim dengan melihat parameter perlindungan krim terhadap terbentuknya eritema pada kulit mencit. Eritema yang muncul pada kulit mencit diolah dan dianalisis dengan ImageJ dan SPSS v23 dengan metode one way anova. Hasil penelitian menunjukkan bahwa ekstrak etanol biji Wali dapat diformulasi menjadi sediaan krim tabir surya dan krim ekstrak etanol biji Wali $1 \%$ tersebut dapat melindungi kulit mencit dari terbentuknya eritema secara signifikan jika dibandingkan dengan kontrol negatif $(p<0.05)$ setelah terpapar sinar UV B. Aktivitas penekanan eritema oleh krim ekstrak etanol biji Wali sebesar $93 \%$.
\end{abstract}

Kata kunci: Formulasi; Uji efektivitas; Krim tabir surya; Ekstrak biji Wali; Eritema

\begin{abstract}
High intensity of ultraviolet (UV) radiation causes several adverse effect such as erythema, sunburn, pigmentation, early senescence, and skin cancer. These effects can be prevented by using sun protection product. Wali (Brucea javanica L. Merr) is one of natural plants that contain phenol and flavonoid. These compounds are proven to have sunscreen effect. The purposes of this studies are to formulate and evaluate the effectivity of oil-in-water-type sunscreen cream using $1 \%$ ethanol extract of Wali seed. The sunscreen cream is developed by using a fusion method and the evaluation of the effectivity is conducted in vivo on the skin of mice (Mus musculus). The formulated sunscreen cream is then tested for its physical properties, including homogenity, $\mathrm{pH}$, spreadability, adhesion, and stability. The effectivity of the formulated cream is also tested by observing the formation of erytema on the skin of mice (Mus musculus). Erythema appearing on the mouse skin is analyzed with ImageJ and SPSS v23 using the one way anova method. The results showed that the ethanol extract of Wali seeds could be formulated into sunscreen cream. Furthermore, the formulated cream was also able to protect the mice skin against the formation of erythema significantly compared to negative controls ( $p$ $<0.05)$ after exposure to UV B light by $93 \%$ erythema inhibition activity.
\end{abstract}

Keywords: Formulation; Effectivity test; Sunscreen cream; Wali seed extract; Erythema 


\section{PENDAHULUAN}

Sinar ultraviolet (UV) yang dipancarkan matahari dibagi menjadi tiga jenis yaitu UV A, UV B, dan UV C. ${ }^{1}$ Saat ini, radiasi sinar UV menjadi salah satu kekhawatiran terbesar bagi masyarakat dunia karena intensitasnya yang semakin meningkat akibat penipisan lapisan ozon. ${ }^{2}$ Tingginya intensitas radiasi UV dapat menimbulkan efek negatif seperti munculnya eritema yang merupakan ciri kerusakan kulit akibat sinar UV. ${ }^{3}$ Paparan sinar UV yang berlebihan juga dapat menimbulkan beberapa masalah lain seperti munculnya sunburn, pigmentasi, dan penuaan dini kulit. $^{4}$

Secara alami, kulit akan menyintesis melanin ketika terpapar sinar UV. Namun, paparan UV yang berlebihan menyebabkan kulit membutuhkan proteksi tambahan agar terhindar dari efek negatif UV. Proteksi tambahan tersebut dapat berupa zat yang mampu mengurangi transmisi sinar UV ke kulit dan dikenal sebagai zat tabir surya. Tabir surya bekerja dengan cara menyerap sinar maupun memantulkan kembali sinar UV yang terpapar ke kulit. ${ }^{5}$

Produk tabir surya di pasaran ditemukan dalam bentuk krim, lotion, maupun spray. ${ }^{4}$ Produk tersebut umumnya mengandung zat kimia sintetis sebagai bahan aktif seperti oksibenzon, avobenzon, turunan PABA ( $p$ - aminobenzoic acid), $\mathrm{TiO}_{2}$ dan $\mathrm{ZnO}^{6}$ Penggunaan senyawa sintetis yang berlebihan sering kali menimbulkan efek alergi, hipersensitivitas, terhambatnya sintetis vitamin $\mathrm{D}$, dan akumulasi bahan tersebut juga dapat menimbulkan risiko kanker melanoma. ${ }^{7}$ Selain itu, bahan aktif seperti $\mathrm{TiO}_{2}$ dan $\mathrm{ZnO}$ yang dikemas dalam bentuk sediaan nanopartikel sering kali memiliki harga yang tinggi sehingga tidak terjangkau masyarakat. ${ }^{8}$ Zat tabir surya dari bahan alam perlu dikembangkan untuk meminimalkan efek samping dan memberikan harga yang lebih terjangkau.

Senyawa bahan alam yang dilaporkan dapat berperan sebagai tabir surya adalah senyawa dengan cincin aromatis seperti golongan fenolik terutama flavonoid. ${ }^{9}$ Salah satu tumbuhan yang dilaporkan memiliki kandungan senyawa fenolik adalah Brucea javanica (L.) Merr yang dikenal dengan nama lokal Wali. ${ }^{10,11}$ Ekstrak etanol biji Wali dilaporkan mengandung metabolit sekunder berupa golongan fenol, polifenol, dan flavonoid. ${ }^{12}$ Senyawa fenolik pada biji Wali diperkirakan sebagai senyawa yang berperan besar menimbulkan efek antioksidan. ${ }^{11}$ Penelitian Bagheri dkk, ekstrak etanol biji Wali memiliki aktivitas antioksidan yang lebih baik dibandingkan dengan asam askorbat dan asam gallat pada konsentrasi $6,25 \mu \mathrm{g} / \mathrm{mL}^{13}$

Kandungan senyawa fenol pada tumbuhan diduga memiliki aktivitas antioksidan dan kemampuan melindungi kulit dari sinar UV. Hal ini sejalan dengan hasil penelitian yang dilakukan oleh Alhabsyi dkk, dimana semakin tinggi aktivitas antioksidan dari suatu tumbuhan, menyebabkan tumbuhan tersebut memiliki kemampuan yang semakin baik dalam melindungi kulit dari sinar UV yang ditandai dengan adanya peningkatan nilai sun protection factor (SPF) dari ekstrak tumbuhan yang diuji. ${ }^{14}$

Masyarakat Indonesia secara empiris telah memanfaatkan tumbuhan Wali sebagai pengobatan tradisional untuk antikanker, antimalaria, penurun demam, antidiabetes, dan antidisentri. ${ }^{15,16}$ Biji Wali yang dimanfaatkan sebagai zat tabir surya belum dikembangkan walaupun bagian buah tersebut memiliki potensi besar untuk dikembangkan sebagai bahan aktif tabir surya.

Penelitian ini bertujuan untuk mengembangkan formulasi krim tabir surya dari ekstrak etanol biji Wali. Krim tabir surya diuji efektivitasnya secara in vivo dengan melihat parameter perlindungan krim terhadap terbentuknya eritema pada kulit mencit.

\section{METODE PENELITIAN}

Desain penelitian ini adalah eksperimental laboratorium. Kegiatan yang dilakukan adalah pembuatan ekstrak, skrining fitokimia ekstrak, pembuatan krim tabir surya, evaluasi sediaan gel, uji 
efektivitas krim tabir surya secara in vivo, dan analisis data.

Penelitian ini telah mendapat persetujuan komite etik Fakultas Kedokteran Universitas Mataram dengan nomor surat persetujuan 50/UN18.F7/ETIK/2019

\section{Alat dan bahan}

Alat yang digunakan adalah inkubator (Sanyo), kotak radiasi UV, lampu UV B 200 (Exoterra), rotary evaporator (Hahn Shin), neraca analitik (Ohaus).

Bahan yang digunakan adalah biji Wali yang diperoleh di daerah Sesaot, Lombok Barat, asam stearat (Ecogreen Oleochemical), etanol (Brataco, 96\%), $\mathrm{FeCl}_{3}$ (Merck, 1\%), gliserin (Ecogreen Oleochemicals), $\mathrm{HCl}$ (Merck, 37\%), indikator universal (Macherey-Nagel), krim depilatories (Veet), lanolin (Wujiang Jinyu), mencit Balb/c, metilparaben (Wuhu Huahai Bio Engineering), metilen biru 0.3 $\%$, propilparaben (Wuhu Huahai Bio Engineering), serbuk magnesium, setil alcohol (Ecogreen Oleochemical), dan trietanolamin (Petronas chemical).

\section{Prosedur kerja}

\section{Pembuatan ekstrak}

Biji Wali sebanyak 1,4 kg dikeringkan dengan tujuan untuk menghilangkan kadar air dari cangkang biji dan mempermudah proses pembukaan cangkang biji. Setelah cangkang biji dipisahkan dari isinya, diperoleh isi biji berwarna putih kekuningan sebanyak $704 \mathrm{~g}$.

Serbuk biji Wali sebanyak $700 \mathrm{~g}$ diekstrak dengan 1,75 L etanol $96 \%$ selama 24 jam dengan metode maserasi. Setelah proses maserasi selesai dilakukan filtrasi untuk memperoleh maserat. Proses ekstraksi diulangi sebanyak 2 kali. Maserat yang diperoleh dipekatkan dengan rotary evaporator pada suhu $40{ }^{\circ} \mathrm{C} . .^{13}$

\section{Skrining fitokimia ekstrak}

Skrining fitokimia dilakukan secara kualitatif dengan metode tabung meliputi uji fenol dengan meneteskan $\mathrm{FeCl}_{3} 1 \%$ dan uji flavonoid dengan meneteskan $\mathrm{HCl}$ dan serbuk Mg pada ekstrak etanol biji Wali.

\section{Pembuatan Krim Tabir Surya}

Campuran fase minyak terdiri dari bahan larut lemak yaitu setil alkohol, lanolin, dan asam stearat dileburkan pada penangas air hingga mencapai suhu $70{ }^{\circ} \mathrm{C}$ kemudian ditambahkan propil paraben. Campuran fase air terdiri dari bahan larut air seperti gliserin dan trietanolamin dileburkan pada sebagian aquades panas hingga mencapai suhu $70 \quad{ }^{\circ} \mathrm{C}$ lalu ditambahkan metil paraben.

Formula sediaan krim tabir surya dibuat dengan mengabungkan ekstrak etanol biji Wali, campuran fase air, dan fase minyak yang digerus secara konstan hingga terbentuk massa krim yang stabil (Tabel 1).

\section{Tabel 1. Formula krim tabir surya}

\begin{tabular}{lcc}
\hline \multicolumn{1}{c}{ Bahan } & Jumlah (\%) & Fungsi \\
\hline Ekstrak biji & 1 & Bahan aktif \\
Wali & 2 & Pengental \\
Setil alkohol & 1 & emolien \\
Lanolin & 5 & Emulgator \\
Asam stearat & 1 & Emulgator \\
Trietanolamin & 10 & Humektan \\
Gliserin & 0.02 & Pengawet \\
Metilparaben & 0.2 & Pengawet \\
Propilparaben & Ad 100 & Pelarut \\
Akuades & & \\
\hline
\end{tabular}

\section{Evaluasi sediaan gel}

1. Organoleptis

Pengamatan organoleptik yang dilakukan meliputi warna dan bau dari sediaan yang telah dibuat. ${ }^{17}$

2. Uji homogenitas

Krim diambil secukupnya dan dioleskan pada lapisan kaca yang rata lalu dilihat apakah masih terdapat butiran kasar atau tidak. ${ }^{17}$

3. Uji pH

Indikator universal dicelupkan dan didiamkan beberapa saat lalu sesuaikan perubahan warna dari indikator universal dengan standar pH universal. ${ }^{18}$

4. Uji daya sebar

Krim sebanyak 0.5 g ditimbang dan diletakkan diantara 2 lapisan kaca 
objek yang diberi beban $100 \mathrm{~g}$. Pengukuran diameter krim yang menyebar dilakukan setelah kurang lebih 1 menit. $^{19}$

5. Uji daya lekat

Krim diletakkan di antara dua kaca objek kemudian diberi beban $1 \mathrm{~kg}$ selama 5 menit. Kedua objek tersebut dipisahkan dengan menarik kaca objek yang di atas dengan beban seberat 80 g, sedangkan kaca objek yang di bawah ditahan dengan beban lainnya. Lamanya waktu yang diperlukan untuk memisahkan kedua objek tersebut dicatat sebagai waktu lekat. ${ }^{19}$

6. Uji stabilitas (Freeze thaw cycle)

Pengujian dilakukan selama enam siklus dengan menyimpan sediaan krim pada suhu $4 \pm 2{ }^{\circ} \mathrm{C}$ selama 24 jam lalu memindahkan sediaan krim pada suhu $40 \pm 2{ }^{\circ} \mathrm{C}$ selama 24 jam (satu siklus). Setelah itu dilakukan pengamatan apakah terdapat pemisahan fase dari sediaan krim. ${ }^{20}$

\section{Uji efektivitas krim tabir surya secara in vivo}

Mencit yang diujikan diaklimatisasi selama 7 hari. Rambut mencit di bagian punggung dihilangkan dengan dengan cara mengolesi krim depilatories sehingga diperoleh luas area punggung mencit yang terpapar kurang lebih $15 \mathrm{~cm}^{2}(3 \times 5 \mathrm{~cm})$. Mencit dibagi menjadi tiga kelompok dimana setiap kelompok terdiri dari 3 ekor mencit. Kelompok pertama yaitu kelompok kontrol negatif yang diaplikasikan basis krim tanpa zat aktif (tidak mengandung ektrak biji Wali), kelompok kedua adalah kelompok perlakuan yang diaplikasikan krim tabir surya ekstrak etanol biji Wali 1 $\%$, dan kelompok ketiga adalah kelompok kontrol ekstrak yang yang hanya diaplikasikan ekstrak etanol biji Wali dengan dosis $30 \mathrm{mg} / 15 \mathrm{~cm}^{2}$. Basis, krim, dan ekstrak biji Wali dibiarkan kontak selama 1 jam dengan kulit mencit. Setiap kelompok akan diberi radiasi menggunakan lampu UV B selama delapan jam..$^{21}$ Eritema yang terbentuk pada kulit mencit diamati setelah 12 jam.

\section{Analisis data}

Luas eritema pada kulit mencit ditentukan menggunakan ImageJ untuk selanjutnya dianalisis dengan metode one way anova menggunakan SPSS v23.

\section{HASIL DAN PEMBAHASAN}

\section{Ekstrak etanol biji Wali}

Biji Wali diperoleh dari daerah Sesaot, Lombok Barat pada koordinat 8'32'44"S $116^{\circ} 14^{\prime} 27^{\prime} \mathrm{E}$. Identifikasi sampel tumbuhan Wali dilakukan di Laboratorium Biologi Dasar, Universitas Mataram dengan nomor surat 46/UN18.7/LB/2018.

Proses ekstraksi biji Wali menggunakan etanol $96 \%$ karena senyawa utama yang diinginkan dalam penelitian ini adalah kelompok senyawa fenol dan flavonoid dimana keduanya memiliki kelarutan yang baik dalam pelarut campuran polar seperti campuran akuades dan etanol. ${ }^{22}$ Rendemen ekstrak etanol biji Wali yang diperoleh sebanyak $7,4 \%$. Rendemen yang diperoleh lebih besar dari penelitian sebelumnya sebesar $2,7 \% .^{13}$ Perbedaan hasil tersebut dapat dipengaruhi oleh kondisi lingkungan yang berbeda seperti adanya perbedaan suhu, alkalinitas, salinitas, radiasi UV, dan infeksi patogen. ${ }^{23}$

\section{Skrining fitokimia}

Hasil pengujian skrining fitokimia ekstrak etanol biji Wali positif mengandung fenol dan flavonoid (Tabel 2).

\section{Tabel 2. Hasil skrining fitokimia ekstrak etanol biji Wali}

\begin{tabular}{lcc}
\hline Senyawa & Hasil & Keterangan \\
\hline Fenol & & Hasil positif ditandai \\
& + & $\begin{array}{c}\text { dengan perubahan warna } \\
\text { larutan menjadi hitam } \\
\text { Flavonoid }\end{array}$ \\
& + & $\begin{array}{c}\text { Hasil positif ditandai } \\
\text { dengan perubahan warna } \\
\text { larutan menjadi orange }\end{array}$ \\
\hline
\end{tabular}

Kelompok senyawa fenol dan flavonoid pada ekstrak biji Wali tersebut sesuai dengan hasil skrinning fitokimia yang 
telah dilakukan sebelumnya oleh Helmi dkk., Rahayu dkk., dan Hasni dkk. ${ }^{12,24,25}$ Selain positif mengandung senyawa fenol dan flavonoid, ekstrak biji Wali juga positif mengandung senyawa seperti alkaloid, tanin, dan triterpenoid. ${ }^{12,26}$

\section{Formulasi krim ekstrak etanol biji Wali}

Pembuatan krim dilakukan dengan metode peleburan dimana semua bahan akan dilebur menjadi satu pada penangas air dan peleburan setiap bahan didasarkan atas penurunan titik leleh. Hal tersebut dilakukan untuk mencegah paparan panas yang berlebihan bagi bahan dengan titik leleh yang lebih rendah sehingga dapat mencegah terjadinya kerusakan bahan. ${ }^{27}$

Pembuatan krim menggunakan konsentrasi ekstrak biji Wali $1 \%$. Pemilihan konsentrasi tersebut berdasarkan perbandingan nilai $\mathrm{IC}_{50}$ Vitamin $\mathrm{E}$ dengan nilai $\mathrm{IC}_{50}$ dari ekstrak biji Wali. Penggunaan vitamin E sebagai pembanding dilakukan karena vitamin E seringkali digunakan dalam kosmetik dengan tujuan mencegah timbulnya eritema/ antiinflamasi. $^{28}$ Dasar pemilihan konsentrasi tersebut digunakan karena belum ada penelitian sebelumnya yang menunjukkan konsentrasi efektif dari ekstrak etanol biji Wali sebagai krim tabir surya.

\section{Evaluasi sediaan krim ekstrak etanol biji Wali}

Evaluasi pertama adalah evaluasi organoleptis meliputi bau dan warna serta homogenitas dari basis dan krim ekstrak etanol biji Wali $1 \%$. Evaluasi terakhir yang dilakukan adalah evaluasi stabilitas dari basis dan krim ekstrak biji Wali $1 \%$. Keduanya disimpan pada suhu berbeda yaitu suhu $40 \pm 2{ }^{\circ} \mathrm{C}$ dan suhu $4 \pm 2{ }^{\circ} \mathrm{C}$ selama 24 jam (satu siklus). Tujuan dari perlakuan tersebut adalah untuk mengetahui efek perubahan suhu terhadap stabilitas sediaan krim. Keadaan basis maupun krim ekstrak biji Wali $1 \%$ setelah dilakukan penyimpanan dipercepat tidak menunjukkan adanya pemisahan fase maupun perubahan organoleptis dari segi warna maupun bau (Tabel 3). Hal tersebut menunjukkan bahwa keduanya bersifat stabil dan tidak mengalami reaksi kimia yang menimbulkan perubahan warna dan bau selama proses penyimpanan dipercepat. $^{30}$

Nilai $\mathrm{pH}$ setelah penyimpanan dipercepat tetap menunjukkan bahwa basis maupun krim ekstrak biji Wali $1 \%$ masih mempertahankan nilai $\mathrm{pH}$ diangka 6 (Tabel 4). Hasil pengamatan dan pengujian kembali terhadap basis dan krim ekstrak etanol biji Wali $1 \%$ setelah penyimpanan dipercepat, maka dapat dikatakan basis maupun krim ekstrak biji Wali dapat mempertahan kestabilannya setelah dilakukan uji penyimpanan dipercepat.

Tabel 3. Hasil pengamatan organoleptis dan homogenitas basis dan krim ekstrak biji Wali $1 \%$

\begin{tabular}{lll}
\hline Parameter & \multicolumn{1}{c}{ Basis } & \multicolumn{1}{c}{ Krim } \\
\hline Bau & $\begin{array}{l}\text { Bau khas } \\
\text { basis }\end{array}$ & $\begin{array}{l}\text { Bau khas } \\
\text { ekstrak biji } \\
\text { Wali } \\
\text { (berbau } \\
\text { kacang } \\
\text { tanah) }\end{array}$ \\
& & $\begin{array}{l}\text { Putih } \\
\text { tulang }\end{array}$ \\
Warna & Putih & Homogen \\
& & \\
\hline
\end{tabular}

Tabel 4. Hasil pengukuran pH, daya sebar, dan daya lekat basis dan krim ekstrak etanol biji Wali $1 \%$

\begin{tabular}{lccc}
\hline Parameter & \multicolumn{1}{c}{ Basis } & \multicolumn{1}{c}{ Krim } & Persyaratan \\
\hline pH & $6,00 \pm 0,00$ & $6,00 \pm 0,00$ & $4-7,5^{18}$ \\
$\begin{array}{l}\text { Daya sebar } \\
\left(\mathrm{cm}^{2}\right)\end{array}$ & $6,20 \pm 0,08$ & $6,04 \pm 0,08$ & $5-7^{29}$ \\
$\begin{array}{l}\text { Daya lekat } \\
\text { (detik) }\end{array}$ & $8,67 \pm 1,25$ & $7,67 \pm 2,62$ & $>4^{29}$ \\
\hline
\end{tabular}

Uji efektivitas krim ekstrak etanol biji Wali secara in vivo

Kelompok mencit pada penelitian ini disinari dengan lampu UV B yang memiliki panjang gelombang $294 \mathrm{~nm}$ selama 8 jam. Lampu UV B dipilih karena sinar UV B bersifat 1000 kali lebih poten dalam menimbulkan eritema jika dibandingkan dengan UV A. ${ }^{31}$ Timbulnya eritema diamati setelah 12 jam penyinaran. Pemilihan waktu pengamatan setelah 12 
jam karena eritema yang ditimbulkan oleh sinar UV B bersifat delayed erythema. Biasanya eritema muncul 6 jam setelah paparan sinar UV B dan mencapai puncaknya setelah 12-24 jam. ${ }^{32}$ Setelah dilakukan penyinaran dan dilakukan pengamatan setelah 12 jam penyinaran, diperoleh hasil berupa munculnya eritema pada kelompok kontrol negatif dan kelompok perlakuan. Sementara itu, kelompok kontrol ekstrak tidak didapati munculnya eritema (Gambar 1).

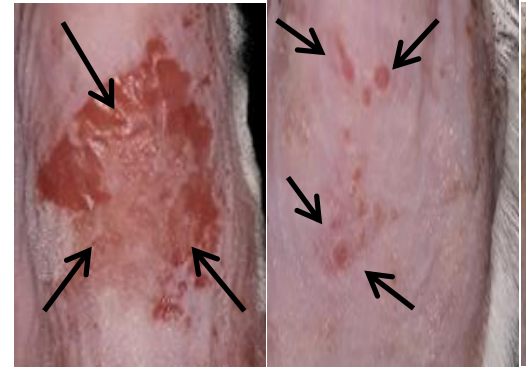

a) b)

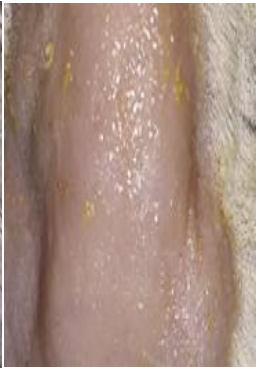

c)
Gambar 1. Efektivitas perlindungan krim ekstrak biji Wali pada kulit mencit terhadap paparan sinar UV B a) Kontrol negatif (mencit diolesi basis krim tanpa ekstrak biji Wali) ; b)

Perlakuan (Diolesi krim ekstrak biji Wali) ; c) Kontrol ekstrak (hanya diolesi ekstrak biji Wali)

Luas eritema yang muncul pada kulit mencit tersebut diolah menggunakan imageJ. Analisis data menggunakan SPSS v23 menunjukkan data luas eritema bersifat normal dan homogen $(p>0.05)$. Uji one way anova dan diperoleh nilai $p=0.032$ yang menunjukkan bahwa terdapat perbedaan signifikan pada kelompok data tersebut. Analisis post hoc selanjutnya dilakukan untuk mengetahui kelompok yang berbeda secara signifikan. Hasil analisis post hoc menunjukkan bahwa rata-rata luas eritema pada kelompok kontrol negatif berbeda signifikan dengan kelompok perlakuan maupun kelompok kontrol ekstrak, sedangkan antara kelompok perlakuan dan kelompok kontrol ekstrak menunjukkan tidak adanya perbedaan signifikan (Tabel 5).
Tabel 5. Luas eritema berdasarkan image J

\begin{tabular}{|c|c|c|c|}
\hline \multirow{2}{*}{$\begin{array}{l}\text { Replikasi } \\
\text { ke - }\end{array}$} & \multicolumn{3}{|c|}{ Luas Eritema $\left(\mathrm{cm}^{2}\right)$} \\
\hline & $\begin{array}{l}\text { Kontrol } \\
\text { Negatif } \\
\end{array}$ & Perlakuan & $\begin{array}{l}\text { Kontrol } \\
\text { Ekstrak }\end{array}$ \\
\hline 1 & 1.079 & 0.325 & 0 \\
\hline 2 & 4.833 & 0.257 & 0 \\
\hline 3 & 2.677 & 0.017 & 0 \\
\hline Rata-rata & $\begin{array}{c}2.863 \pm \\
1,538^{\mathrm{a}}\end{array}$ & $\begin{array}{c}0.199 \pm \\
0,132^{b}\end{array}$ & $\begin{array}{c}0 \pm \\
0,000^{b}\end{array}$ \\
\hline
\end{tabular}

Ket: Huruf yang berbeda menunjukkan adanya perbedaan signifikan $(\mathrm{p}<0.05)$

Hasil uji lua eritema menunjukkan bahwa basis krim yang diolesi pada mencit kelompok kontrol negatif tidak dapat memberikan efek perlindungan terhadap kulit mencit yang disinari dengan lampu UV B. Eritema tersebut muncul dikarenakan pada basis tidak terdapat senyawa aktif yang mampu menyerap sinar UV B yang dipaparkan ke kulit mencit, akibatnya sinar UV B tersebut akan menginisiasi pelepasan mediator-mediator inflamasi pada daerah kulit seperti histamin dan prostaglandin (PG) yang menyebabkan terjadinya vasodilatasi. Terjadinya vasodilatasi menyebabkan aliran darah dan infiltrasi leukosit ke jaringan kulit meningkat dan akhirnya terjadi eritema pada kulit. ${ }^{33}$ Pada fase awal terjadinya eritema baik pada manusia maupun hewan uji seperti mencit, histamin diduga berperan dalam menimbulkan eritema tersebut akibat destabilisasi sel mast. $^{34}$ Selain histamin, terdapat pula mediator lain yang diduga berperan dalam menimbulkan dan mempertahan eritema hingga 48-72 jam. Mediator inflamasi tersebut adalah prostaglandin yang disintesis oleh enzim siklooksigenase (COX) dari asam arakidonat. Peranan prostaglandin pada late phase erythema dibuktikan melalui penelitian berupa pemberian indometasin yang merupakan obat golongan NSAID (Non Steroid Antiinfalamatory Drug) secara berulang pada beberapa responden dapat menekan kemunculan eritema setelah 24 jam pemaparan dengan sinar UV B. ${ }^{35}$ Kadar prostaglandin akan mencapai puncaknya pada 18-24 jam setelah terpapar sinar UV 
B. ${ }^{36}$ Sintesis prostaglandin pada kasus eritema didominasi COX-2 dikarenakan radiasi UV merupakan salah satu stimulus yang dapat menginisiasi kerja COX-2 di epidermis. ${ }^{37}$ Ekspresi dari COX 2 juga akan meningkat 24 jam setelah paparan sinar UV B. ${ }^{32}$ Aktifnya COX-2 akan meningkatkan sintesis prostaglandin beserta metabolitnya terutama $\mathrm{PGE}_{2}$ dan $\mathrm{PGD}_{2}{ }^{36}$

Hasil penyinaran juga membuktikan bahwa krim ekstrak biji Wali $1 \%$ dan ekstrak biji Wali mampu memberikan perlindungan terhadap kulit mencit yang ditunjukkan dengan tidak terbentuknya eritema pada kulit mencit yang diolesi ekstrak biji Wali dan muncul eritema minimal pada kulit mencit yang diolesi krim ekstrak biji Wali. Kemampuan formula krim ekstrak biji Wali $1 \%$ dalam melindungi kulit mencit dari paparan sinar UV B secara statistik tidak berbeda signifikan dengan ekstrak biji Wali. Apabila dihitung secara matematis, pengolesan krim ekstrak biji Wali $1 \%$ mampu menghambat munculnya eritema sebesar $93 \%$. Nilai tersebut diperoleh dengan cara membandingkan selisih rata-rata luas eritema pada kelompok kontrol negatif dan kelompok perlakuan dengan rata-rata luas dari eritema yang muncul pada mencit kelompok kontrol negatif. Namun, ketika dilihat secara visual, kulit mencit yang diolesi krim ekstrak biji Wali masih menimbulkan eritema dengan luas rata-rata sebesar $0.199 \pm 0.132 \mathrm{~cm}^{2}$. Salah satu faktor yang memungkinkan eritema masih timbul adalah jumlah dosis zat aktif yang terlalu kecil (underdosage).

Kemampuan ekstrak maupun formula dalam melindungi kulit mencit dari munculnya eritema setelah paparan sinar UV B disebabkan karena keduanya mengandung senyawa metabolit skunder fenol dan flavonoid. Hampir seluruh kelompok senyawa fenol dan flavonoid dilaporkan memiliki kemampuan fotoproteksi karena dapat menyerap radiasi UV. ${ }^{38}$ Penyerapan sinar UV oleh flavonoid akan menyebabkan terjadinya perubahan struktur dari flavonoid tersebut (Gambar 2).

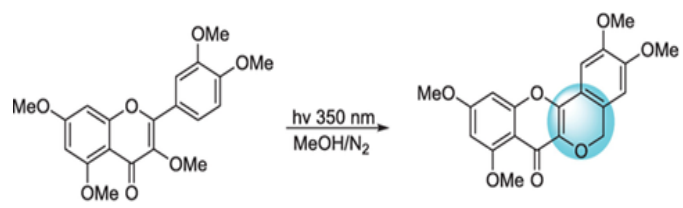

\section{Gambar 2. Penyerapan sinar UV oleh quersetin pentametil eter ${ }^{39}$}

Mekanisme flavonoid dalam melindungi kulit dari paparan sinar UV adalah dengan cara menyerap sinar UV yang berpenetrasi ke kulit. Flavonoid memiliki struktur berupa ikatan rangkap terkonjugasi sehingga hampir seluruh flavonoid dapat berperan sebagai kromofor. $^{40}$ Flavonoid akan menyerap sinar UV dan menyebabkan terjadinya eksitasi elektron dari keadaan ground state menuju orbital dengan energi yang lebih tinggi. ${ }^{37}$ Ketika mencit disinari dengan lampu UV B, maka flavonoid pada ekstrak maupun pada formula krim, akan menyerap sinar UV B yang memapar kulit mencit tersebut, dan ketika elektron kembali ke keadaan semula, sinar UV B yang diserap selanjutnya akan diemisikan namun dengan energi yang jauh lebih kecil. Sebagian besar energi sinar UV B, oleh flavonoid diubah menjadi energi panas yang tidak berbahaya untuk kulit. Mekanisme tersebut selanjutnya akan menghambat atau meminimalkan munculnya eritema akibat paparan dari sinar UV.

Flavonoid juga diperkirakan memiliki aktivitas antiinflamatori yang bekerja pada jalur arakidonat. Flavonoid dapat menghambat ekspresi dari COX-2 sehingga sintesis prostaglandin seperti $\mathrm{PGI}_{2}$ dan $\mathrm{PGE}_{2}$, yang berperan penting dalam patogenesis eritema yang diinduksi oleh sinar UV juga akan terhambat. ${ }^{36}$

\section{KESIMPULAN}

Formula krim tabir surya ekstrak biji Wali $1 \%$ dapat diformulasi menjadi sediaan krim dan mampu memberikan perlindungan terhadap kulit mencit dari terbentuknya eritema setelah dipaparkan dengan sinar lampu UV B. 


\section{DAFTAR RUJUKAN}

1. Ahmad, Shamim I, editors. Ultaviolet light in human health, diseases, and environment. Switzerland: Springer; 2017.

2. McKenzie R. UV radiation in the melanoma capital of the world: What makes New Zealand so different? American Institute of Physics Conferency Proceedings. 2017;1810(1):1-8.

3. Saewan N, Jimtaisong A. Photoprotection of natural flavonoids. Journal of Applied Pharmaceutical Science. 2013;3(9):12941.

4. Isfardiyana S, Safitri S. Pentingnya melindungi kulit dari sinar ultraviolet dan cara melindungi kulit dengan sunblock buatan sendiri. Jurnal Inovasi dan Kewirausahaan. 2014;3(2):126-33.

5. Ahmad I, Agus ASR. Uji stabilitas formula krim tabir surya ekstrak umbi bawang dayak (Eleutherine americana L. Merr.). Journal of Tropical Pharmacy and Chemistry. 2013; 2(3):159-65.

6. Latha MS, Martis J, Shobha V, Sham SR, Bangera S, Krishnankutty B, et al. Sunscreening agents: A review. The Journal of Clinical Aesthetic Dermatology. 2013; 6(1):16-26.

7. Fauzi AR, Rina N. Merawat kulit dan wajah. Jakarta: Gramedia; 2012.

8. Gadri A, Darijono ST, Mauludin R, Iwo MI. Formulasi sediaan tabir surya dengan bahan aktif nanopartikel cangkang telur ayam broiler. Jurnal Matematika dan Sains. 2012;17(3):89-97.

9. Hogade MG, Patil B, Prashant D. Comparative sun protection factor determination of fresh fruits extract of cucumber vs marketed cosmetic formulation. Research Journal of Pharmaceutical Biological and Chemical Sciences. 2010;1(3):55-9.

10. Hamdin CD, Muliasari H, Ihsan M. Efek hipoglikemis suspensi biji buah Wali (Brucea javanica (L.) Merr pada tikus Diabetes. BioWallace JIIB. 2017;3(2):8893.

11. Ablat A, Mohamad J, Awang K, Shilpi JA, Arya A. Evaluation of antidiabetic and antioxidant properties of Brucea javanica seed. The Scientific World Journal:2014:1-8.

12. Helmi H, Susanti I, Agung NA, Kusen S. Antibacterial activity of belilik (Brucea javanica (L). Merr) growth of enteropathogenic bacteria. Journal of Biological Research. 2015. 21(1):35-40.

13. Bagheri E, Hajiaghaalipour F, Nyamathulla S, Salehen N. The apoptotic effects of Brucea javanica fruit extract against HT29 cells associated with p53 upregulation and inhibition of NF- $\mathrm{KB}$ translocation. Dovepress. 2018;12:657-71.

14. Alhabsyi DF, Suryanto E, Wewengkang DS. Aktivitas antioksidan dan tabir surya pada ekstrak kulit buah pisang goroho (Musa acuminate L.). Pharmacon. 2014;3(2):107-14.

15. Achmad, SA, Hakim EH, Makmur L, Syah YM, Juliawaty LD, Mujahidin D. Ilmu kimia dan kegunaan tumbuh tumbuhan obat indonesia jilid 1 . Bandung: Penerbit ITB; 2009.

16. Muliasari H, Hamdin $\mathrm{CD}$, Ananto $\mathrm{AD}$ IM. Hypoglycemic effect of Brucea javanica (L) Merr leaves and seed extract in alloxan-induced diabetic rats. Proceeding of $2^{\text {nd }}$ International Conference on Science and Technology. 2017:62-7.

17. Dewi R, Anwar E, Yunita KS. Uji stabilitas fisik formula krim yang mengandung ekstrak kacang kedelai (Glycine max). Pharmaceutical Sciences and Research. 2014. 1(3):194-208.

18. Yumas M. Formulasi sediaan krim wajah berbahan aktif ekstrak metanol biji kakao non fermentasi (Theobroma cacao L) kombinasi madu lebah. Jurnal Industri Hasil Perkebunan. 2016; 11(2):75-87.

19. Azkiya $Z$, Ariyani $H$, Nugraha $T$. Evaluasi sifat fisik krim ekstrak jahe merah (Zingiber officinale Rosc. var. rubrum) sebagai antinyeri. Journal of Current Pharmaceutical Sciences. 2017;1(1):12-8.

20. Oktaviasari L, Zulkarnain A. Formulasi dan uji stabilitas fisik sediaan lotion o/w pati kentang (Solanum Tuberosum L.) serta aktivitasnya sebagai tabir surya. Majalah Farmaseutik. 2017;13(1):9-27.

21. Eff ARY, Pertiwi RD, Rakhmawati I, Utami TP. In-vitro and in-vivo sunscreen activity of active compounds isolated from fruits of Phaleria marcocarpha (Scheff.) Boerl. Journal of Young Pharmacist. 2018;10(2s):S10610. 
22. Rao USM, Abdurrazak M, Mohd KS. Phytochemical screening, total flavonoid and phenolic content assays of various solvent extracts of tepal of musa paradisiaca penyaringan fitokimia, jumlah asai kandungan flavonoid dan fenolik pelbagai ekstrak pelarut tepal Musa paradisiaca. Malaysian Journal of Analytical Sciences. 2016; 20(5):1181-90.

23. Ramakrishna A, Ravishankar G. Influence of abiotic stress signals on secondary metabolites in plants. Plant Signaling \& Behavior. 2011;6(11):1720-31.

24. Rahayu MP, Wiryosoendjoyo K, Prasetyo A. Uji aktivitas antibakteri ekstrak soxhletasi dan maserasi buah makassar (Brucea javanica L. Merr) terhadap bakteri Shigella dysentriae ATCC 9361 secara in-vitro. Jurnal Biomedika. 2012. 2(1).

25. Hasni KU, Lubees ZIZ, Mohamad J, Varman M. Brucea javanica seeds as source of potential natural antioxidants to improve biodisel thermal and oxidative stability. Malaysian Journal of Fundamental and Applied Sciences. 2017;13(3):207-12.

26. Pandiangan CPP. Aktivitas buah makassar (Brucea javanica (L.) Merr) sebagai antikanker. Journal of agromedicine unila. 2015;2(2):113-7.

27. Agarwal P. Pharmaceutical calculations. New York: Jones \& Bartlett Learning; 2016.

28. Butler H. Poucher's perfumes, cosmetics and soaps $10^{\text {th }}$ edition. Dordretcht. Kluwer Academic Publisher; 2000.

29. Ulaen SPJ, Banne Y SR. Pembuatan salep anti jerawat dari ekstrak rimpang temulawak (Curcuma xanthorrhiza Roxb.). Jurnal Ilmiah Farmasi. 2012;3(2):45-9.

30. Shankar R, Sarangi B, Gupta R, Pathak K. Formulation and characterization of polyherbal cream for skin manifestations. Journal of Asian Association of Schools of Pharmacy. 2016;1:360-6.

31. Roberths SM, James RC, Williams PL. Principles of toxicology environmental and industrial applications third edition, New Jersey: John Wiley \& Sons; 2015.
32. Grimes PE. Aesthetic and cosmetic surgery for darker skin type. Philadephia: Lippincot Williams \& Wilkins; 2008.

33. Rhodes L, Gledhill K, Masoodi M, Haylett A, Brownrigg M, Thody A, et al. The sunburn response in human skin is characterized by sequential eicosanoid profiles that may mediate its early and late phases. The Federation of American Scienties for Experimental Biology Journal. 2009; 23(11):3947-56.

34. Ruzicka, T. Eicosanoids and the Skin. Florida. CRC Press; 2000.

35. Rhodes L, Belgi G, Parslew R, McLoughlin L, Clough G, Friedmann P. Ultraviolet-B-induced erythema is mediated by nitric oxide and prostaglandin E2 in combination. Journal of Investigate Dermatology. 2001;117(4):880-5.

36. Auerbach, P, Cushing T, Harris NS. Auerbach's wilderness medicine seventh edition. New York: Elsevier Health Sciences; 2016.

37. Elmets CA, Ledet J, Athar M. Cyclooxygenases: Mediators of UVinduced skin cancer and potential targets for prevention. Journal of Investigate Dermatology. 2014;134(10):2497-502.

38. Afaq S, Katiyar SK. Polyphenols: skin photoprotection and inhibition of photocarcinogenesis. Mini-Reviews in Medicinal Chemistry. 2011;11(14):1200-15.

39. Cetinkaya H, Kulak M, Karaman M, Karaman HS, Kocer F. Flavonoid accumulation behavior in response to the abiotic stress: can a uniform mechanism be illustrated for all plants ?. Intech Open Scienc. 2017. 151-65.

40. Sisa M, Bonnet SL, Ferreira D, Van Der Westhuizen JH. Photochemistry of flavonoids. Molecules. 2010; 15(8):5196-245. 